\title{
Design, synthesis and binding affinity of new nicotinic ligands
}

\section{Luca Guandalini, ${ }^{a}$ Elisabetta Martini, ${ }^{\text {a }}$ Paola Gratteri, ${ }^{\text {a }}$ Carla Ghelardini, ${ }^{\text {b }}$ Katia Varani, and Maria Novella Romanelli ${ }^{\text {a* }}$}

${ }^{a}$ Dipartimento di Scienze Farmaceutiche, Laboratorio di Progettazione, Sintesi e Studio di Eterocicli Biologicamente Attivi, Polo Scientifico, Università di Firenze, Via Ugo Schiff, 6, 50019 Sesto Fiorentino, (FI), Italy. ${ }^{b}$ Dipartimento di Farmacologia Preclinica e Clinica, Università di Firenze, Viale Pieraccini 6, I-50139 Firenze, Italy. 'Istituto di Farmacologia, Università di Ferrara, via Fossato di Mortara 17-19, I-44100 Ferrara, Italy

E-mail: novella.romanelli@unifi.it

\begin{abstract}
Nicotinic ligands can be potentially useful as drugs for the management of several important pathologies as well as pharmacological tools to characterize nicotinic receptor subtypes. The design of new nicotinic ligands has been carried out by applying the 3D database search method; thus, the Cambridge Structural Database has been scanned with a query consisting in a pharmacophore substructure with 3D constraints. The nicotinic pharmacophoric features have been obtained from the structure of pyrido[3,4-b]homotropane (PHT), which represents a rigid template. The results of the query suggested the aminoalkylquinoline moiety as simple scaffold, and it was further refined using molecular modeling. Some of the synthesized compounds were found to interact with the central nicotinic receptor on rat cerebral cortex, showing affinity in the nanomolar range and displaying analgesic properties. The possible binding mode of these substances with a homology-built model of the nicotinic receptor has been analyzed by means of induced fit studies.
\end{abstract}

Keywords: Nicotinic receptor, docking studies, subtype selectivity

\section{Introduction}

Neurodegenerative disorders are characterized by a progressive and irreversible loss of neurons in the CNS. Their aetiology is unknown, but genetic alterations, oxidative stress, environmental factors, excitotoxicity and age are thought to be important risk factors. Degeneration is localized in specific areas of the CNS and it is characterized by particular histopathological changes, some of which are due to the formation of amorphous protein deposits known as amyloid. These "misfolded" proteins adopt $\beta$-sheet structures and aggregate spontaneously into similar extended 
fibrils despite their widely divergent primary sequences. Many of these peptides can form ionpermeable channels in vitro and possibly in vivo, and this may be relevant for their toxicity. ${ }^{1}$

Probably the best studied amyloid deposit is that found in Alzheimer's disease (AD). The pathological changes described in the post mortem brains of Alzheimer disease patients include senile plaques, which are formed by 40 - or 42 -amino-acid peptides called amyloid- $\beta$, whose level in the brain correlates with the onset and severity of memory impairments. This peptide, particularly the 42-amino-acid form, is highly hydrophobic and accumulates both extracellularly in plaques and intracellularly. Soluble extracellular amyloid- $\beta$ may initiate memory impairments before the accumulation of plaques.

$\mathrm{AD}$ is a form of dementia characterized by a deficit in the central cholinergic transmission, caused by degeneration of the basal forebrain cholinergic neurons innervating cortex and hippocampus, which produces difficulties in attention and cognitive impairment. Pharmacological treatment based on the "cholinergic hypothesis" has led to the development of acetylcholinesterase inhibitors: tacrine, donepezil, galanthamine and rivastigmine are the only drugs approved for AD together with memantine, ${ }^{2,3}$ which is classified as an antagonist of the glutamatergic NMDA receptor, although it has been recently reported that it blocks the $\alpha 7$ receptor in hippocampal neurons more potently than NMDA receptors. ${ }^{4,5}$

A significant loss of nicotinic cholinergic receptors (nAChR) has been found in post mortem brains of AD patients, and a deficit of nAChRs is observed also in vivo by means of positron emission tomography (PET) studies; a significant correlation has been found between nicotinic deficit and cognitive impairment. ${ }^{6}$ Moreover, epidemiological studies have suggested that smokers exhibit a lower incidence of AD and Parkinson's Disease (PD), and there are several studies reporting the neuroprotective effect of nicotine under several kinds of neurotoxic conditions. ${ }^{7}$

Nicotine is the prototype of agonists for the nicotinic receptors, which are the best studied members of the family of Ligand Gated Ion Channels (LGIC). They are composed of five subunits assembled to form a cation permeable pore. To date, $17 \mathrm{nAChR}$ subunits have been cloned, and among them five are muscle-type and the others are found in neurons and sensory epithelia. While the five muscle-type nAChR subunits have been found to assemble into only two possible combinations ( $\alpha 2 \beta \gamma \delta$ or $\alpha 2 \beta \varepsilon \delta$ ), the 12 neuronal nAChR subunits can form a large number of $\mathrm{nAChR}$ subtypes, differing in terms of ligand pharmacology, cation permeability, activation and desensitization kinetics. Studies using cloned receptors have shown that the $\alpha(2-6)$ and $\beta(2-4)$ subunits are involved in the formation of heteropentameric nAChR complexes, while the $\alpha 7, \alpha 8$, and $\alpha 9$ subunits form homopentameric receptor complexes, and the $\alpha 10 \mathrm{nAChR}$ subunit cannot form a functional $\mathrm{nAChR}$ alone, but it does together with $\alpha 9$. As far as native neuronal receptors are concerned, the predominant nAChR subunits in the CNS are $\alpha 4, \beta 2$, and $\alpha 7$, whereas $\alpha 3$ and $\beta 4$ are the prevalent subunits in the periphery. The majority of nAChRs in the CNS (about $90 \%$ ) are $\alpha 4 \beta 2 *$ receptors, and $\alpha 7 * \mathrm{nAChR}$ is the other major CNS subtype. The distribution of the other $\mathrm{AAChR}$ subunits in the CNS is much more limited. ${ }^{8}$ 
The agonist binding sites are located at the interface between $\alpha$ and non- $\alpha$ subunits, and are formed by a principal component (loops A-C on the $\alpha$ subunit) and the complementary component (loops D-E on the non- $\alpha$ subunit). The number of possible binding sites depends on the number (and type) of $\alpha$ subunits in the stoichiometry of the receptor: therefore, in the muscletype there are two non-equivalent binding sites at the $\alpha-\gamma$ and $\alpha-\delta$ interfaces, while in the neuronal-type the binding sites are two ( $\alpha-\beta$ interface) in the heteromeric receptor and five in the homomeric receptor.

nAChRs are located both pre- and post synaptically; presynaptic nAChRs modulate the release of ACh, glutamate and other neurotransmitters throughout the CNS. ${ }^{9}$ Regarding the function of nicotinic receptors, a lot of work has been performed using knock-out mice, showing that deletion of $\alpha 4$ and $\beta 2$ subunits affects locomotion, reinforcement and memory and learning, ${ }^{10}$ which explains the pharmacological effects of nicotine.

Several nicotinic agonists from different chemical classes have been studied in cognition models, and some of them have also entered clinical trials for AD: both $\alpha 4 \beta 2$ and $\alpha 7$ selective agonists show cognition-enhancing properties, being able to induce long-term potentiation (LTP), through an increase in glutamatergic transmission obtained by activating an $\alpha 4 \beta 2$ presynaptic receptor on cholinergic neurons, or an $\alpha 7$ receptor on glutamatergic neurons. ${ }^{11}$ Moreover, as far as $\mathrm{AD}$ is concerned, there is evidence that the nicotinic receptor may be the target of the toxic effect of $A \beta_{1-42 .}{ }^{12}$ In fact, it has been reported that $A \beta_{1-42}$ binds with high affinity to nicotinic receptors, causing activation at picomolar doses and inhibition at higher doses, the non- $\alpha 7$ being more sensitive than the $\alpha 7 .{ }^{13-16}$ The action of $A \beta_{1-42}$ through the $\alpha 7$ nicotinic receptor has, as a consequence, a reduction of glutamatergic transmission and an inhibition of synaptic plasticity. ${ }^{17}$

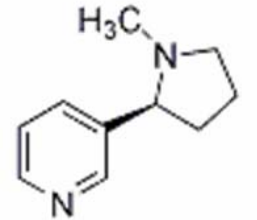

nicotine

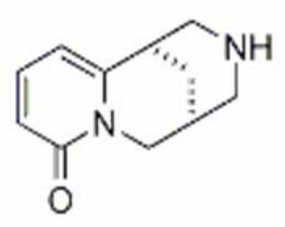

cytisine

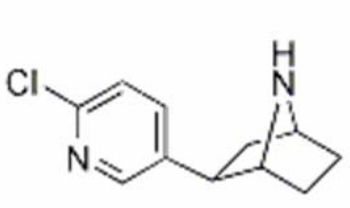

epibatidine

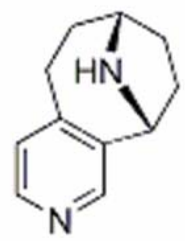

PHT<smiles>CN1CCC[C@H]1COc1cccnc1</smiles><smiles>c1cnc2cc3c(cc2n1)[C@H]1CNC[C@H]3C1</smiles>

varenicline<smiles>COC(=O)c1ccccc1NC(c1ccccc1)c1ccc2cccnc2c1O</smiles>

VIFLAX

\section{Chart 1}


It is worth highlighting that the importance of the nicotinic receptor is due not only to its involvement in $\mathrm{AD}$ and $\mathrm{PD}$, but also into a variety of psychiatric disorders or pathological conditions. Involvement of nicotinic receptor in schizophrenia and depression was first suggested by the high percentage of smokers among schizophrenics; ${ }^{18}$ there is evidence that the $\alpha 7$ nicotinic receptor expression and function is reduced in such patients, which suggests to consider $\alpha 7$ selective full or partial agonists as possible therapeutic interventions. ${ }^{19}$ A relationships has also been found between smoke and depression, ${ }^{20}$ and both agonists (such as nicotine) and antagonists are effective in animal models of depression. ${ }^{21,22}$ Several nicotinic agonists are under development as analgesics, ${ }^{23}$ and ABT-089, a compound in phase II for AD, is also under evaluation for Attention-Deficit Hyperactivity Disorder (ADHD) in adults. ${ }^{24}$ Varenicline, an orally active $\alpha 4 \beta 2$ nicotinic partial agonist, is now in clinical trials for smoking cessation. ${ }^{25}$ Finally, nicotinic antagonists may be useful in autism and in some forms of genetic epilepsy. ${ }^{26,27}$

It is obviously important to determine which subtype of nicotinic receptor is involved in each of these disorders, in order to design specific modulators, but this is made difficult by the high number of subunits that can co-assemble in many different ways, by the low abundance of some of them in the brain, and by the lack of selective ligands to study the role of nAChR under physiological or pathological conditions. So the search for new and selective nicotinic ligands is still very important.

\section{Results and Discussion}

The design of new nicotinic ligands has been performed in different ways. Historically, the most popular approach starts from natural products such as nicotine, cytisine or epibatidine as lead compounds; ${ }^{28}$ the design and synthesis of varenicline is a recent example of drug design starting from the cytisus alkaloid cytisine (Chart 1). ${ }^{29}$ Rapid progress in the techniques developed for structural biology studies is expected to make the structure-based drug design approach possible; at present, the homology models based on the X-ray structures of Acetylcholine Binding Protein (AChBP) ${ }^{30-33}$ representing only the extracellular part of the receptor which contains the ligand binding domain, have been used mainly to rationalize existing data. ${ }^{34-37}$ Recently, models of the whole muscle-type ${ }^{38}$ or $\alpha 7^{39}$ receptors, based on the cryo-electron microscopy data of the membrane domain collected on Torpedo Marmorata nAChRs, ${ }^{40}$ have been developed, and hopefully they will overcome the limitations inherent to the previous models. ${ }^{41}$ 
<smiles>CCN(C)Cc1cnc2ccccc2c1</smiles>

$\mathrm{Ki} 1110 \mathrm{r} \mathrm{M}^{52}$<smiles>CN(C)c1cccc2ncccc12</smiles>

$\mathrm{Ki} 450 \mathrm{ni}^{52}$<smiles>CN1CCCC1c1cnc2ccccc2c1</smiles>

$\mathrm{Ki} 11.2 \mathrm{nM} \mathrm{M}^{54}$<smiles>[R]N(CC)C1CCCC2=NCCC=C21</smiles>

$\mathrm{R}=\mathrm{H}, \mathrm{CH}_{3}$
no affinity<smiles>CCN(C)CCOc1cnc2ccccc2c1</smiles>

$\mathrm{Ki} 2470 \mathrm{n} \mathrm{M}^{54}$<smiles>CN1CCC[13C]1COc1ccc2cccnc2c1</smiles>

$\mathrm{Ki} 5000 \mathrm{nM}^{55}$<smiles>[X]Cc1ccc2cccnc2c1</smiles>

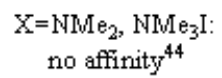<smiles>[X]Cc1cccc2ncccc12</smiles>

$\mathrm{X}=\mathrm{NMe_{2 }}, \mathrm{NMIE}_{3} \mathrm{I}:$ no affirity ${ }^{44}$<smiles>[X]Cc1ccc2ncccc2c1</smiles>

see table $\mathrm{I}^{44}$

\section{Chart 2}

To look for new ideas for the discovery of novel nicotinic ligands, we thought it interesting to apply the 3D database searching approach, ${ }^{42}$ a method which was used, although with some differences, almost 20 years ago by Sheridan and Venkataraghavan. ${ }^{43}$ Therefore, ${ }^{44}$ the Cambridge Structural Database was scanned with a suitable query, searching for compounds showing the pharmacophoric features typical for the interaction with the nicotinic receptor: an $\mathrm{H}-$ bond acceptor group and a potentially-cationic nitrogen at a certain distance and with a precise spatial orientation. The query was built up starting from the structures of pyrido[3,4b]homotropane (PHT): ${ }^{45,46}$ this is a fully rigid high affinity ligand, showing the two pharmacophoric points at a distance of $4.75 \AA$. The proposed values for this pharmacophoric feature range from 4.5 to $6.1 \AA$. $^{47-49}$ 
Table 1. Binding affinity of compounds 1-13 and nicotine ${ }^{a}$
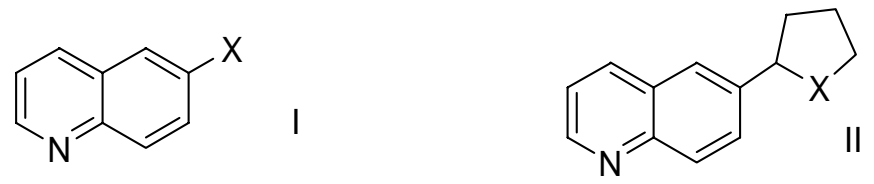

\begin{tabular}{cccc}
\hline $\mathbf{N}$ & structure & $\mathbf{X}$ & $\mathbf{K}_{\mathbf{i}}(\mathbf{n M})$ \\
\hline $\mathbf{1}$ & $\mathrm{I}$ & $\mathrm{CH}_{2} \mathrm{NMe}_{2}$ & $6000 \pm 497$ \\
$\mathbf{2}$ & $\mathrm{I}$ & $\mathrm{CH}_{2} \mathrm{NHMe}$ & $>10.000$ \\
$\mathbf{3}$ & $\mathrm{I}$ & $\mathrm{CH}_{2} \mathrm{CH}_{2} \mathrm{NMe}_{2}$ & $>10.000$ \\
$\mathbf{4}$ & $\mathrm{I}$ & $\mathrm{CH}_{2} \mathrm{NMe}_{3} \mathrm{I}$ & $150 \pm 6$ \\
$\mathbf{5}$ & $\mathrm{I}$ & $\mathrm{CH}_{2} \mathrm{CH}_{2} \mathrm{NMe}_{3} \mathrm{I}$ & $>10.000$ \\
$\mathbf{6}$ & II & $\mathrm{NMe}$ & $132 \pm 8$ \\
$\mathbf{7}$ & II & $\mathrm{NMe}_{2} \mathrm{I}$ & $45 \pm 2$ \\
nicotine & & & $6.8 \pm 0.3$ \\
\hline
\end{tabular}

${ }^{\text {a }}$ Displacement of $\left[{ }^{3} \mathrm{H}\right]$-cytisine from rat cortical membranes. See ref. 50 for the experimental protocol. Data taken from ref. 44

Among all the output structures found in the hit set, the quinoline derivative VIFLAX ${ }^{51}$ (Chart 1) was chosen and its structure simplified in order to give molecules (derived from 7aminomethylquinoline) able to interact with the nicotinic receptor. Other quinoline derivatives, designed as ligand for the nicotinic receptor, have already been reported in the literature (Chart 2). Glennon and coworkers ${ }^{52}$ showed that 5 -dimethylaminoquinoline was able to displace $\left[{ }^{3} \mathrm{H}\right]$ nicotine from the nicotinic receptor in rat brain homogenate $\left(\mathrm{K}_{\mathrm{i}} 450 \mathrm{nM}\right)$, while 5-ethylamino5,6,7,8-tetrahydroquinoline and its $\mathrm{N}$-methyl derivative are devoid of affinity; ${ }^{53}$ the same group reported that 3-( $N$-ethyl- $N$-methylamino)methyl-quinoline and 3-( $N$-ethyl- $N$ methylamino)ethoxyquinoline showed affinity in the micromolar range, while 3-(2pyrrolidinyl)quinoline was 9-fold less potent than nicotine. ${ }^{54}$ Elliott reported that (S)-7-(2pyrrolidinyl)methoxyquinoline was able to displace $\left[{ }^{3} \mathrm{H}\right]$-cytisine from rat brain homogenate (Ki $5000 \mathrm{nM}) .^{55}$

The 7-(dimethylaminomethyl)quinoline was synthesized and tested together with its isomers in position 5, obtained as by-product from the same synthetic procedure, and $\mathbf{1}$, its isomers in position 6 , suggested by molecular modelling studies. Since binding studies showed that only the 6-substituted quinolines possess some affinity (Chart 2, Table 1), a structure optimization study was performed only on compound $\mathbf{1}$ in order to improve binding affinity: ${ }^{44}$ while $\mathrm{N}$-dealkylation or homologation gave inactive compounds ( 2 and 3 , respectively), the freezing of the alkylamino moiety into a pyrrolidine ring was successful since the resulting compound $\mathbf{6}$ shows nanomolar affinity for the nicotinic receptor of rat cerebral cortex. Quaternarization of the nitrogen then increased affinity of both $\mathbf{1}$ and $\mathbf{6}$, although the effects of this modification are different if we 
consider the cyclic derivative (the affinity of 7 is 3 -fold higher that 6 ) or the linear compound (4 is 40 -fold more active than 1). It must be remembered that the introduction of a permanent positive charge on nicotinic ligands produces in some instances an increase and in others a decrease of affinity; ${ }^{56}$ these differences may reflect a different mode of binding of the quaternary ammonium ligands to the nicotinic receptor with respect to their amino derivatives, and/or different steric effects within the binding site. ${ }^{50,57}$

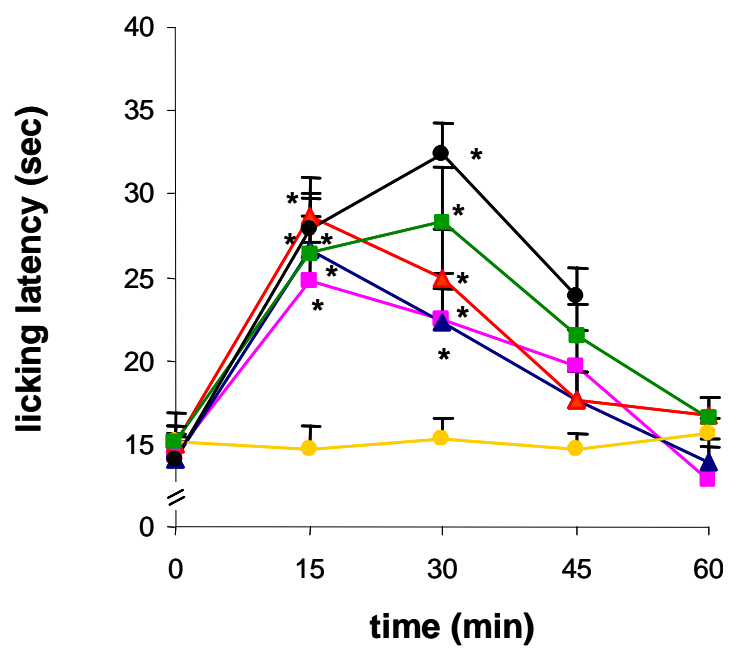

Figure 1. Analgesic activity (mice hot-plate test) of compounds 4 ( $25 \mu \mathrm{g} / \mathrm{mouse}$, magenta), 6 (12.5 $\mu \mathrm{g} /$ mouse, blue), 7 (12.5 $\mu \mathrm{g} / \mathrm{mouse}$, red) and 11 (12.5 $\mu \mathrm{g} / \mathrm{mouse}$, green). Epibatidine (50 ng/mouse, black) was used as reference compound. Each point represents the means of at least 8 mice. The compounds were injected i.c.v. See ref. 50 for the experimental protocol. ${ }^{*} \mathrm{P}<0.05$ in comparison with saline-treated mice (orange).

To check whether these compounds behave as agonists, the analgesic activity of the most active substances was measured by means of the hot-plate test on mice (Figure 1). ${ }^{50,58}$ All the tested compounds, when injected intracerebroventricularly (i.c.v.), are able to induce an analgesic effect which is completely prevented by mecamylamine at the dose of $5 \mathrm{mg} / \mathrm{kg}$ i.p. (data not shown). This means that they are able to activate the central nicotinic system, their potency being qualitatively in agreement with their rank order of affinity.

Compounds 1 and 6 (as well as their methiodides 4 and 7) show a distance between the Hbond acceptor aromatic nitrogen and the cationic nitrogen of 6.5-6.6 $\AA$, therefore higher than that proposed by pharmacophoric models, ${ }^{47-49}$ but in the same range as that obtained considering the additional water molecule which connects the nicotine pyridyl nitrogen and the protein in the crystal structure of the complex between AChBP and nicotine. The possible presence of a water molecule is the basis of the "water-extension concept", 59 which suggests that a short ligand such as nicotine (N-N distance $4.8 \AA$ ) can be transformed into a longer ligand whose distance between 
the cationic nitrogen and the $\mathrm{H}$-bond forming group (pyridyl nitrogen or water oxigen) is higher (6.7 $\AA$ in the crystal structure); this would explain the wide range of the proposed pharmacophoric distances. In addition, the water molecule could allow the interaction of the protein with a ligand having an H-bond acceptor as well as donor group in the suitable position.

Chart 3<smiles>CN1CCN(c2cccc(O)c2)CC1</smiles>

Ki 8nM (ref 50)

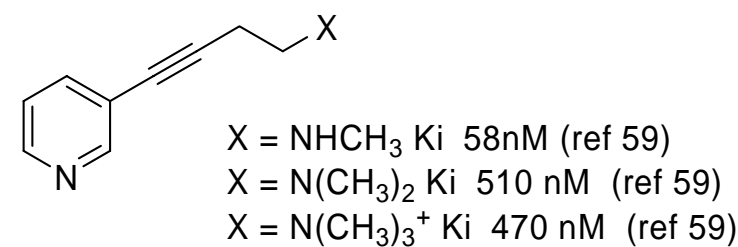

$\mathrm{X}=\mathrm{N}\left(\mathrm{CH}_{3}\right)_{3}^{+} \mathrm{Ki} 470 \mathrm{nM}($ ref 59$)$

However, ligands are known for which the pharmacophoric distance is higher even than that found for nicotine and water: for instance (Chart 3), in 4-(3'-hydroxyphenyl)-1,1dimethylpiperazinium iodide (the phenol analogue of DMPP), the distance between the H-bond forming group and the cationic nitrogen is $7.5 \AA$, while for 4-(3-pyridyl)but-3-yn-1-amines the low energy conformers have distances higher than $8 \AA \AA^{59}$ Both compounds are reported to bind with nanomolar affinity to the receptor. ${ }^{50,60}$ So it can be suggested that ligands dock into the active site in a way that allows them to interact with different residues according to their own distance between the pharmacophoric points. In this regard, a recently-published study also predicts different binding modes of nicotinic ligands within the active site of the receptor. ${ }^{37}$
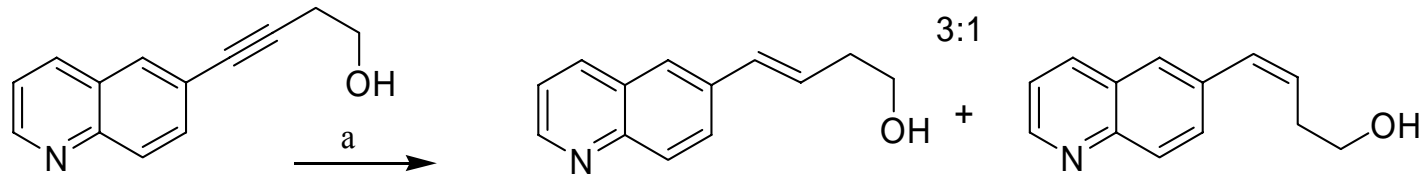<smiles>CNCCC#Cc1ccc2ncccc2c1</smiles>

8<smiles>CN(C)CCC#Cc1ccc2ncccc2c1</smiles>

11

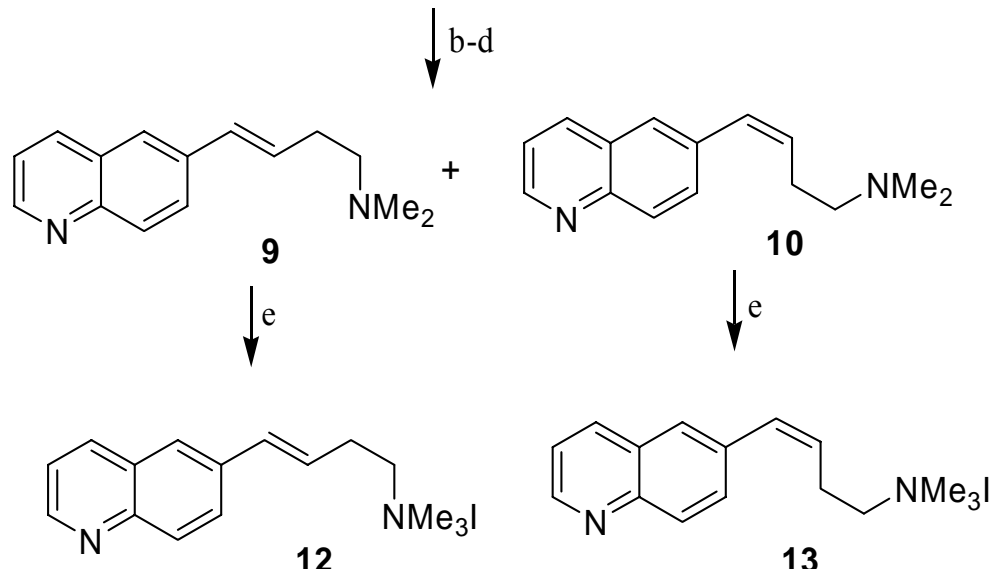

12

13

Scheme 1. a) $\mathrm{LiAlH}_{4}$; b) $\mathrm{CH}_{3} \mathrm{SO}_{2} \mathrm{Cl}$, pyridine; c) $\mathrm{Me}_{2} \mathrm{NH}$; d) column chromatography; e) MeI. 
We thought it interesting to synthesize longer ligands in order to explore the breadth of the binding site. Therefore, we designed compounds 8-13: these ligands have pharmacophoric distances greater than $8 \AA$ (the cis alkenes 10 and 13), $9 \AA$ (the trans alkenes 9 and 12) or $10 \AA$ (the butynes 8 and 11). ${ }^{61}$ Their synthesis started from 4-(6-quinolinyl)but-3-yn-1-ol ${ }^{44}$ which was transformed into the amine via the methanesulfonate and then quaternarized. $\mathrm{LiAlH}_{4}$ reduction of the triple bond gave a mixture of the cis and trans alkenes in a 1:3 ratio, which was transformed via the methanesulfonate into the corresponding mixture of amines and then separated by column chromatography; the amines were then transformed into the corresponding methiodides (Scheme I). ${ }^{62}$

Binding studies (Table 2) showed that only the methiodides $\mathbf{1 1}$ and $\mathbf{1 2}$ were able to displace $\left[{ }^{3} \mathrm{H}\right]$ cytisine from rat cerebral cortex, while tertiary amines 8-10 and methiodide $\mathbf{1 3}$ were completely devoid of affinity. Pharmacological results indicate that long compounds that are able to interact with the receptor behave as agonists: in fact, the alkyne $\mathbf{1 1}$ shows analgesic properties (Figure 1) with an efficacy comparable to that of the other quinolines although its affinity is 10fold lower than that of the pirrolidinium compound 7 .

Table 2. Binding affinity of compounds 8-13 and nicotine ${ }^{\mathrm{a}}$<smiles>[X]c1ccc2ncccc2c1</smiles>

\begin{tabular}{ccc}
\hline $\mathbf{N}$ & $\mathbf{X}$ & $\mathbf{K}_{\mathbf{i}}(\mathbf{n M})$ \\
\hline $\mathbf{8}$ & $\mathrm{C} \equiv \mathrm{CCH}_{2} \mathrm{CH}_{2} \mathrm{NMe}_{2}$ & $>10.000$ \\
$\mathbf{9}$ & trans $-\mathrm{CH}=\mathrm{CHCH}_{2} \mathrm{CH}_{2} \mathrm{NMe}_{2}$ & $>10.000$ \\
$\mathbf{1 0}$ & cis- $\mathrm{CH}=\mathrm{CHCH}_{2} \mathrm{CH}_{2} \mathrm{NMe}_{2}$ & $>10.000$ \\
$\mathbf{1 1}$ & $\mathrm{C} \equiv \mathrm{CCH}_{2} \mathrm{CH}_{2} \mathrm{NMe}_{3} \mathrm{I}$ & $500 \pm 47$ \\
$\mathbf{1 2}$ & trans $-\mathrm{CH}=\mathrm{CHCH}_{2} \mathrm{CH}_{2} \mathrm{NMe}_{3} \mathrm{I}$ & $1350 \pm 165$ \\
$\mathbf{1 3}$ & cis- $\mathrm{CH}=\mathrm{CHCH}_{2} \mathrm{CH}_{2} \mathrm{NMe}_{3} \mathrm{I}$ & $>10.000$ \\
nicotine & & $6.8 \pm 0.3$ \\
\hline
\end{tabular}

${ }^{a}$ Displacement of $\left[{ }^{3} \mathrm{H}\right]$-cytisine from rat cortical membranes; see ref. ${ }^{50}$ for the experimental protocol. For biological tests, the tertiary amines were transformed into the water-soluble oxalate salts.

To see how these compounds could interact with the active site of the $\alpha 4 \beta 2$ receptor, the model of the rat $\alpha 4 \beta 2$ nicotinic receptor (PDB code 1OLE) built by homology modelling on the structure of AChBP (PDB code 1I9B) ${ }^{35}$ was used, applying the Schrödinger induced-fit docking protocol. ${ }^{63}$ In the induced-fit docking both the receptor and the ligand change shape so that they more closely conform to each other. The protocol uses the suites Glide for ligand-receptor docking and Prime for the protein structure prediction. It works inducing adjustments in the 
receptor structure and generating multiple poses of the ligand complex, each including unique structural modifications of the receptor to fit the ligand pose. The rank of these poses, achieved by means of the Glide score function, ${ }^{64}$ allows finding the best structure of the docked complex. From an experimental point of view, default parameters were used, and the binding mode of nicotine, epibatidine and other derivatives was compared to that of the quinoline ligands synthesized in this study. The geometry of the resulting complexes are reported in Figures 2-4.

In Figure 2 the binding modes of nicotine, as found in the crystal structure of the complex with AChBP (left), ${ }^{31}$ and docked into the rat $\alpha 4 \beta 2$ receptor model (right) are compared. In both cases the ${ }^{+} \mathrm{NH}$ group of nicotine establishes an H-bond with the carbonyl of Trp147 (Trp143 in $\mathrm{AChBP}$ ), and makes $\pi$-cation interactions with the indole ring of the same triptophane and other tyrosine residues; in the crystal structure, a H-bond is found between the pyridyl nitrogen and a water molecule, which on the other hand interacts with the $\mathrm{CO}$ of Leu112 and the $\mathrm{NH}$ of Met114. In the docking complex the orientation of the heteroaromatic ring is similar, but, since water molecules were not included in the docking experiments, no H-bond is established. ${ }^{65}$
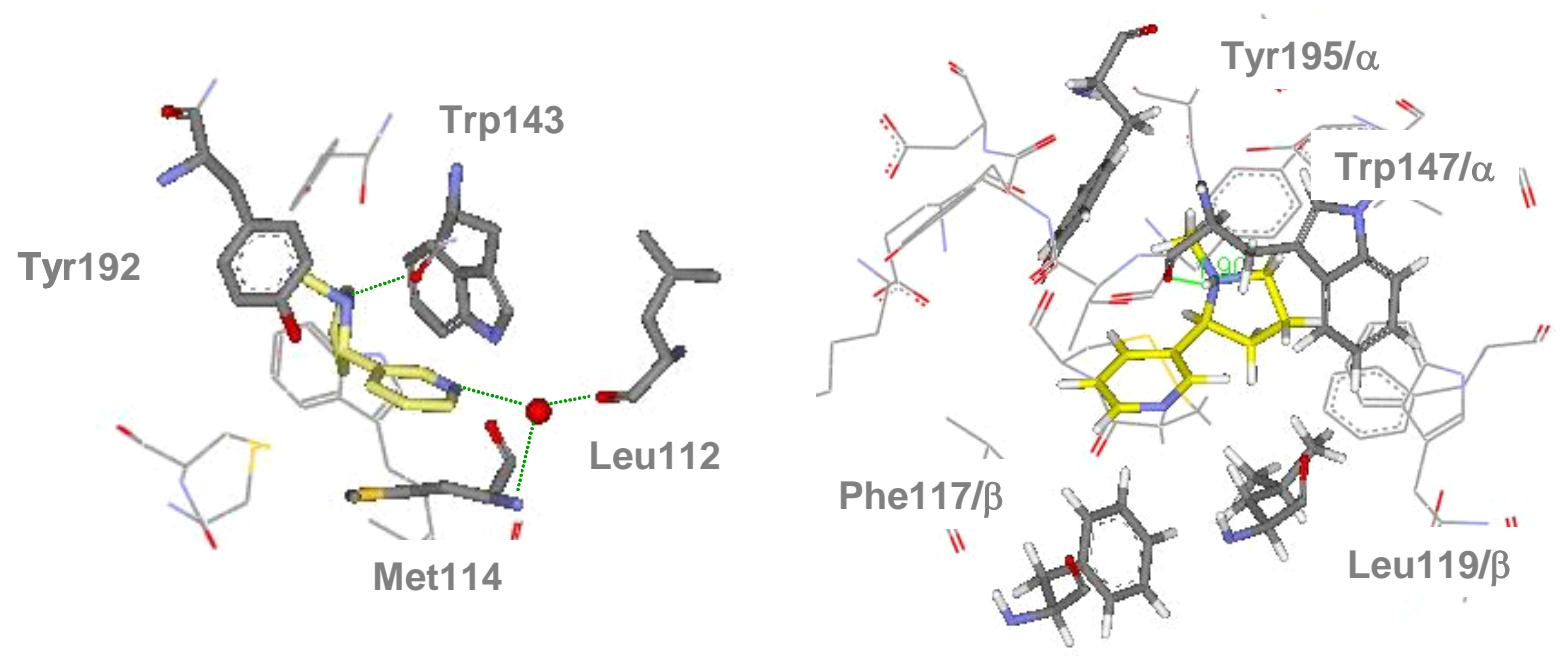

Figure 2. Binding mode of (S)-nicotine in the active site of AChBP (left) and in the binding site of rat $\alpha 4 \beta 2$ receptor model (right). Nicotine is shown as stick models, with their $\mathrm{C}$ atom yellow. The residues interacting with the ligands, as well as Phe117 and Leu119, are shown as stick models. Hydrogen bond interactions are shown in green. 


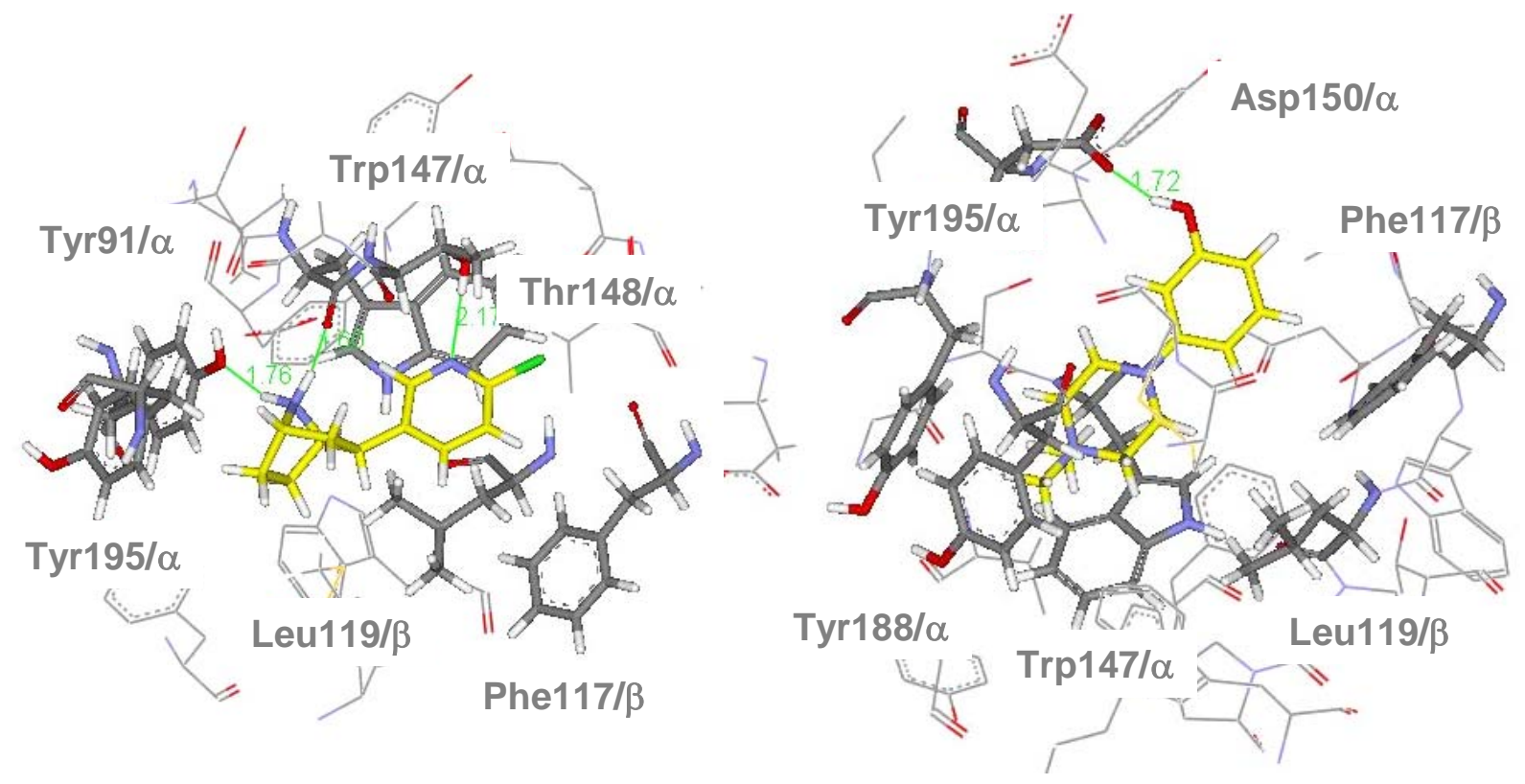

Figure 3. Docking of $(1 R, 2 R, 4 S)$-epibatidine (left) and 3-OH-DMPP (right) in the binding site of rat $\alpha 4 \beta 2$ receptor model. Ligands are shown as stick models, with their $\mathrm{C}$ atom yellow. The residues interacting with the ligands, as well as Phe117 and Leu119 in the $\beta$ subunit, are shown as stick models. Hydrogen bond interactions are shown in green.

The binding of $(1 R, 2 R, 4 S)$-epibatidine (Figure 3 , left) with the rat $\alpha 4 \beta 2$ receptor model is predicted to occur through two hydrogen bonds of the ${ }^{+} \mathrm{NH}_{2}$ group with the carbonyl of Trp147 and the phenolic $\mathrm{OH}$ of Tyr91, while the pyridyl nitrogen accepts a H-bond from Thr148 hydroxyl group. This orientation is somehow different from that found by other researchers which applied a standard (no induced fit) docking procedure on the same model 1 OLE. ${ }^{37} 3$ Hydroxy-DMPP (Figure 3, right), being a quaternary ammonium derivative, can only establish $\pi$-cation interactions with the aromatic residues of the binding site, while making a H-bond through the phenol OH with Asp150, a residue shown by site-directed mutagenesis studies on the muscle-type receptor to be involved in the binding of agonists and competitive antagonists. ${ }^{66}$

In Figure 4 the docking of the quinoline derivatives $\mathbf{6}$ and $\mathbf{7}$ is reported. The $(\mathrm{S})$ isomer of the tertiary amine $6^{67}$ docks in a way similar to that of nicotine, therefore establishing H-bond and $\pi$ cation interaction with Trp147, but, as for nicotine, the heteroaromatic nitrogen is not involved in a direct H-bond with the receptor, even though it is directed towards Leu119/ $\beta$, the analogue of the AChBP residue Met114. On the contrary, the ammonium derivative 7 can establish a H-bond with the $\varepsilon$-amino group of Lys77 in addition to $\pi$-cation interactions with Trp147 and other aromatic residues; this is made possible by the lack of H-bond involving the cationic nitrogen, thus allowing a slightly different arrangement of this ammonium derivative within the binding site. 

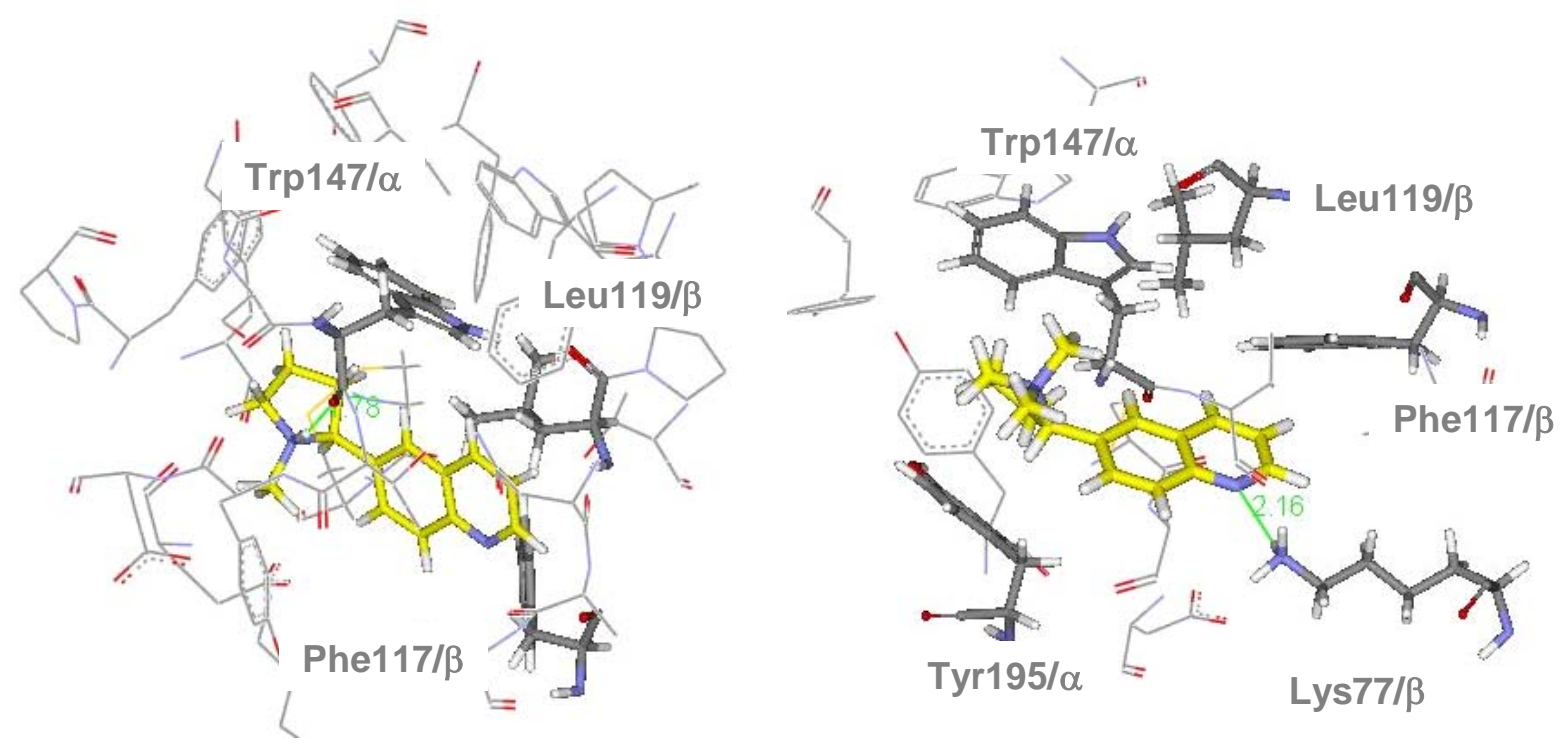

Figure 4. Docking of (S)-6 (left) and (S)-7 (right) in the binding site of rat $\alpha 4 \beta 2$ receptor model. Ligands are shown as stick models, with their $\mathrm{C}$ atom yellow. The residues interacting with the ligands, as well as Phe117 and Leu119 in the $\beta$ subunit, are shown as stick models. Hydrogen bond interactions are shown in green. The (S)-isomer of $\mathbf{6}$ is docked with the protonated nitrogen atom in the $\mathrm{R}$ configuration.

The docking of the alkyne $\mathbf{1 1}$ into the active site of the receptor (Figure 5) results in a binding mode similar to 7: the anchoring $\pi$-cation interaction with Trp147 in the $\alpha$ subunit allows the quinoline ring to be inserted more deeply into the $\beta$ subunit, making a strong H-bond with Lys161. Since the kind of $\beta$ subunit is thought to be the major factor in determining agonist affinity, ${ }^{68}$ the synthesis of agonists able to interact more deeply into the $\beta$ subunits may be useful to find new selective ligands, as recently demonstrated by Kozikowski and coworkers. ${ }^{69}$

\section{Conclusions}

In conclusion, we have synthesized new nicotinic agonists that can be useful as tools to study the breadth of the binding site of the receptor; these compounds will be characterized further by checking selectivity for the nicotinic receptor subtypes and enantioselectivity (as far as the pyrrolidine derivatives are concerned); hopefully they can give useful suggestions also for designing selective ligands for the characterization of nicotinic receptor subtype. 


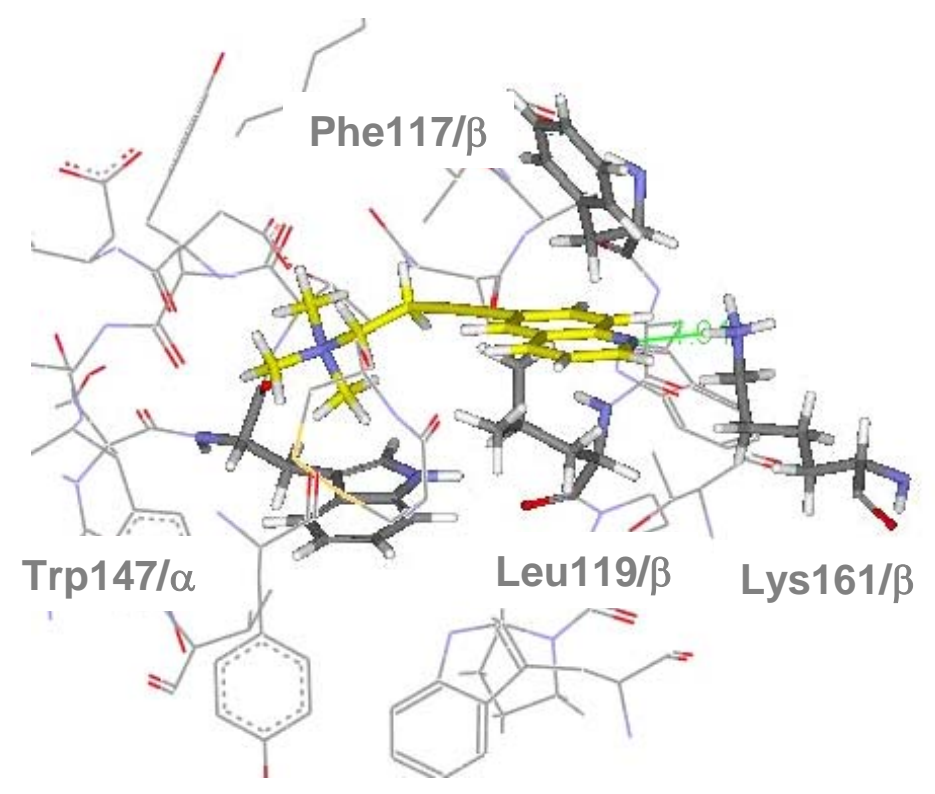

Figure 5. Docking of (S)-11 in the binding site of rat $\alpha 4 \beta 2$ receptor model; 11 is shown as stick models, with their $\mathrm{C}$ atom yellow. The residues interacting with the ligands, as well as Phe117 and Leu119 in the $\beta$ subunits, are shown as stick models. Hydrogen bond interactions are shown in green.

\section{References}

1. Kagan, B. L.; Azimov, R.; Azimova, R. J. Membrane Biol. 2004, 202, 1.

2. Scarpini, E.; Scheltens, P.; Feldman, H. Lancet Neurol. 2003, 2, 539.

3. Tariot, P. N.; Federoff, H. J. Alzheimer Dis. Assoc. Disord. 2003, 17, S105.

4. Aracava, Y.; Pereira, E. F. R.; Maelicke, A.; Albuquerque, E. X. J. Pharmacol. Exp. Ther. 2005, 312, 1195.

5. Banerjee, P.; Samoriski, G.; Gupta, S. J. Pharmacol. Exp. Ther. 2005, 313, 928.

6. Nordberg, A. Biol. Psychiatry 2001, 49, 200.

7. Singh, A.; Potter, A.; Newhouse, P. IDrugs 2004, 7, 1096.

8. Jensen, A. A.; Frølund, B.; Liljefors, T.; Krogsgaard-Larsen, P. J. Med. Chem. 2005, 48, 4705.

9. Sher, E.; Chen, Y.; Sharples, T. J.; Broad, L. M.; Benedetti, G.; Zwart, R.; McPhie, G. I.; Pearson, K. H.; Baldwinson, T.; De Filippi, G. Curr. Top. Med. Chem. 2004, 4, 283.

10. Picciotto, M. R.; Caldarone, B. J.; Brunzell, D. H.; Zachariou, V.; Stevens, T. R.; King, S. L. Pharmacol. Ther. 2001, 92, 89.

11. Buccafusco, J. J.; Letchworth, S. R.; Bencherif, M.; Lippiello, P. M. Trends Pharmacol. Sci. 2005, 26, 352.

12. Dougherty, J. J.; Wu, J.; Nichols, R. A. J. Neurosci. 2003, 23, 6740. 
13. Dineley, K. T.; Bell, K.; Bui, D.; Sweatt, J. D. J. Biol. Chem. 2002, 277, 25056.

14. Fu, W.; Jhamandas, J. H. J. Neurophysiol. 2003, 90, 3130.

15. Pettit, D. L.; Shao, Z.; Yakel, J. L. J. Neurosci. 2001, 21, RC120.

16. Lamb, P. W.; Melton, M. A.; Yakel, J. L. J. Mol. Neurosci. 2005, 27.

17. Snyder, E. M.; Nong, Y.; Almeida, C. G.; Paul, S.; Moran, T.; Choi, E. Y.; Nairn, A. C.; Salter, M. W.; Lombroso, P. J.; Gouras, G. K.; Greengard, P. Nat. Neurosci. 2005, 8, 1051.

18. Hogg, R. C.; Raggenbass, M.; Bertrand, D. Rev. Physiol. Biochem. Pharmacol. 2003, 147, 1.

19. Deutsch, S. I.; Rosse, R. B.; Schwartz, B. L.; Weitzman, A.; Chilton, M.; Arnold, D. S.; Mastropaolo, J. Isr. J. Psychiatry Relat. Sci. 2005, 42, 33.

20. Araki, H.; Suemaru, K.; Gomita, Y. Jpn. J. Pharmacol. 2002, 88, 133.

21. Popik, P.; Krawczyk, M.; Kos, T.; Nalepa, I.; Kowalska, M.; Witarski, T.; AntkiewiczMichaluk, L.; Vetulani, J. Eur. J. Pharmacol. 2005, 515, 128.

22. Caldarone, B. J.; Harrist, A.; Cleary, M. A.; Beech, R. D.; King, S. L.; Picciotto, M. R. Biol. Psychiatry 2004, 56, 657.

23. Jain, K. K. Curr. Opin. Investigat. Drugs 2004, 5, 76.

24. Wilens, T. E.; Verlinden, M. H.; Adler, L. A.; Wozniak, P. J.; West, S. A. Biol. Psychiatry 2006, in press.

25. Fagerström, K.; Balfour, D. Expert Opin. Investing. Drugs 2006, 15, 107.

26. Lippiello, P. M. Med. Hypotheses 2006, 66, 985.

27. Hogg, R. C.; Bertrand, D. Bioorg. Med. Chem. Lett. 2004, 14, 1859.

28. Daly, J. W. Cell. Mol. Neurobiol. 2005, 25, 513.

29. Coe, J. W.; Brooks, P. R.; Vetelino, M. G.; Wirtz, M. C.; Arnold, E. P.; Huang, J.; Sands, S. B.; Davis, T. I.; Lebel, L. A.; Fox, C. B.; Shrikhande, A.; Heym, J. H.; Schaeffer, E.; Rollema, H.; Lu, Y.; Mansbach, R. S.; Chambers, L. K.; Rovetti, C. C.; Schulz, D. W.; Tingley, F. D. I.; O'Neill, B. T. J. Med. Chem. 2005, 48, 3474.

30. Brejc, K.; van Dijk, W. J.; Klaassen, R. V.; Schuurmans, M.; van der Oost, J.; Smit, A. B.; Sixma, T. K. Nature 2001, 411, 269.

31. Celie, P. H. N.; van Rossum-Fikkert, S. E.; van Dijk, W. J.; Brejc, K.; Smit, A. B.; Sixma, T. K. Neuron 2004, 41, 907.

32. Celie, P. H. N.; Kasheverov, I. E.; Mordvintsev, D. Y.; Hogg, R. C.; van Nierop, P.; van Elk, R.; van Rossum-Fikkert, S. E.; Zhmak, M. N.; Bertrand, D.; Tsetlin, V.; Sixma, T. K.; Smit, A. B. Nat. Struct. Mol. Biol. 2005, 12, 582.

33. Celie, P. H. N.; Klaassen, R. V.; van Rossum-Fikkert, S. E.; van Elk, R.; van Nierop, P.; Smit, A. B.; Sixma, T. K. J. Biol. Chem. 2005, 280, 26457.

34. Schapira, M.; Abagyan, R.; Totrov, M. BMC Struct. Biol. 2002, 2, 1.

35. Le Novère, N.; Grutter, T.; Changeux, J.-P. Proc. Natl. Acad. Sci. U.S.A. 2002, 99, 3210.

36. Costa, V.; Nistri, A.; Cavalli, A.; Carloni, P. Br. J. Pharmacol. 2003, 140, 912.

37. Bisson, W. H.; Scapozza, L.; Westera, G.; Mu, L.; Schubiger, P. A. J. Med. Chem. 2005, 48, 5123.

38. Unwin, N. J. Mol. Biol. 2005, 346, 967. 
39. Taly, A.; Delarue, M.; Grutter, T.; Nilges, M.; Le Novère, N.; Corringer, P.-J.; Changeux, J.P. Biophys. J. 2005, 88, 3954.

40. Miyazawa, A.; Fujiyoshi, Y.; Unwin, N. Nature 2003, 423, 949.

41. Cassels, B. K.; Bermúdez, I.; Dajas, F.; Abin-Carriquiry, J. A.; Wonnacott, S. Drug Discovery Today 2005, 10, 1657.

42. Martin, Y. C. J. Med. Chem. 1992, 35, 2145.

43. Sheridan, R. P.; Venkataraghavan, R. J. Comput.-Aided Mol. Des. 1987, 1, 243.

44. Guandalini, L.; Martini, E.; Dei, S.; Manetti, D.; Scapecchi, S.; Teodori, E.; Romanelli, M. N.; Varani, K.; Greco, G.; Spadola, L.; Novellino, E. Bioorg. Med. Chem. 2005, 13, 799.

45. Kanne, D. B.; Abood, L. G. J. Med. Chem. 1988, 31, 506.

46. Kanne, D. B.; Tomizawa, M.; Durkin, K. A.; Casida, J. E. Bioorg. Med. Chem. Lett. 2005, 15,877 .

47. Beers, W. H.; Reich, E. Nature 1970, 225, 917.

48. Glennon, R. A.; Herndon, J. L.; Dukat, M. Med.Chem. Res. 1994, 4, 461.

49. Abreo, M. A.; Lin, N.-H.; Garvey, D. S.; Gunn, D. E.; Hettinger, A.-M.; Wasicak, J. T.; Pavlik, P. A.; Martin, Y. C.; Donnelly-Roberts, D. L.; Anderson, D. J.; Sullivan, J. P.; Williams, M.; Arneric, S. P.; Holladay, M. W. J. Med. Chem. 1996, 39, 817.

50. Romanelli, M. N.; Manetti, D.; Scapecchi, S.; Borea, P. A.; Dei, S.; Bartolini, A.; Ghelardini, C.; Gualtieri, F.; Guandalini, L.; Varani, K. J. Med. Chem. 2001, 44, 3946.

51. Rericha, A.; Seidal, I.; Robisch, G. Cryst. Res. and Technol. 1990, 25, 1049.

52. Glennon, R. A.; Maarouf, A.; Fahmy, S.; Martin, B.; Fan, F.; Yousif, M.; Shafik, R. M.; Dukat, M. Med. Chem. Res. 1993, 2, 546.

53. Dukat, M.; Fiedler, W.; Dumas, D.; Damaj, M. I.; Martin, B. R.; Rosecrans, J. A.; James, J. R.; Glennon, R. A. Eur. J. Med. Chem. 1996, 31, 875.

54. Lee, M.; Dukat, M.; Liao, L.; Flammia, D.; Damaj, M. I.; Martin, B.; Glennon, R. A. Bioorg. Med. Chem. Lett. 2002, 12, 1989.

55. Elliott, R. L.; Kopecka, H.; Gunn, D. E.; Lin, N.-H.; Garvey, D. S.; Ryther, K. B.; Holladay, M. W.; Anderson, D. J.; Campbell, J. E.; Sullivan, J. P.; Buckley, M. J.; Gunther, K. L.; O'Neill, A. B.; Decker, M. W.; Arneric, S. P. Bioorg. Med. Chem. Lett. 1996, 6, 2283.

56. Schmitt, J. D. Curr. Med. Chem. 2000, 7, 749.

57. Beene, D. L.; Brandt, G. S.; Zhong, W.; Zacharias, N. M.; Lester, H. A.; Dougherty, D. A. Biochemistry 2002, 41, 10262.

58. O'Callaghan, J. P.; Holtzman, S. G. J. Pharmacol. Exp. Ther. 1975, 192, 497.

59. Glennon, R. A.; Dukat, M. Bioorg. Med. Chem. Lett. 2004, 14, 1841.

60. Dogruer, D.; Lee, M.; Dukat, M.; Damaj, M. I.; Martin, B.; Glennon, R. A. Bioorg. Med. Chem. Lett. 2004, 14, 523.

61. Compounds, in all the possible conformations, were built using Spartan (V 1.01, Wavefunction) and geometry optimized using AM1.

62. Experimental conditions: a) $\mathrm{LiAlH}_{4}$ (1.5 eq), an. THF, $2 \mathrm{hr}, \mathrm{RT}$; b) $\mathrm{CH}_{3} \mathrm{SO}_{2} \mathrm{Cl}$ (1.2 eq), pyridine (10 eq), $\mathrm{CHCl}_{3}, 2$ hrs, RT; c) $\mathrm{Me}_{2} \mathrm{NH}$ (33\% solution in EtOH), $\mathrm{iPrOH}, 60{ }^{\circ} \mathrm{C}, 2 \mathrm{hrs}$; 
d) column chromatography; silicagel, abs. $\mathrm{EtOH} / \mathrm{CH}_{2} \mathrm{Cl}_{2} / \mathrm{Et} 2 \mathrm{O} /$ pet. ether $/ \mathrm{NH}_{4} \mathrm{OH}$ 180:360:360:900:10 as eluent; e) $\mathrm{MeI}, \mathrm{Et}_{2} \mathrm{O}, 1$ day in dark, RT. All intermediate and final compounds have been characterized by $\left[{ }^{1} \mathrm{H}\right]$ and $\left[{ }^{13} \mathrm{C}\right] \mathrm{NMR}$. The elemental analysis of the final compounds are within $0.4 \%$ of the theoretical values.

63. Schrödinger Induced Fit Protocol using Glide 3.5 and Prime 1.2. (http://www.schroedinger.com) Default input parameters were used for the induced-fit computations, i.e. 0.5 scaling factor for the $\mathrm{vdW}$ radii of both ligand and receptor; refinement of residues within $5 \AA$ from the ligand poses, 20 poses of the docked complex.

64. Jorgensen, W. L.; Maxwell, D. S.; Tirado-Rives, J. J. Am. Chem. Soc. 1996, 118, 11225.

65. Work is in progress to include the water molecules in the docking studies.

66. Arias, H. R. Neurochem. Int. 2000, 36, 595.

67. Compound 6 has been studied only as racemate; the (S) isomer has been used for docking studies. The protonation on the pyrrolidine nitrogen introduces a second stereogenic centre; both SR and SS isomers have been docked into the receptor, but only the SR isomer is shown in this work.

68. Parker, M. J.; Beck, A.; Luetje, C. W. Mol. Pharmacol. 1998, 54, 1132.

69. Wei, Z.-L.; Xiao, Y.; Yuan, H.; Baydyuk, M.; Petukhov, P. A.; Musachio, J. L.; Kellar, K. J.; Kozilowski, A. P. J. Med. Chem. 2005, 48, 1721. 